\title{
INDUCTION OF SINGLE STRAND SCISSION IN BACTERIOPHAGE $\phi$ X174 REPLICATIVE FORM I DNA BY MITOMYCIN C
}

\author{
Kazumitsu Ueda, Junji Morita and Tohru Komano \\ Laboratory of Biochemistry, Department of Agricultural Chemistry, \\ Kyoto University, Kyoto 606, Japan
}

(Received for publication November 25, 1980)

\begin{abstract}
The action of mitomycin $\mathrm{C}$ on double-stranded replicative form I DNA (RF I DNA; supercoiled, covalently closed, circular duplex DNA) of bacteriophage $\phi$ X174 was investigated using the technique of agarose gel electrophoresis. Mitomycin $\mathrm{C}$ reduced with sodium hydrosulfite (sodium dithionite, $\mathrm{Na}_{2} \mathrm{~S}_{2} \mathrm{O}_{4}$ ) caused single strand scission in $\phi$ X174 RF I DNA in the presence of $\mathrm{Cu}^{2+}$. $\mathrm{Cu}^{2+}$ was essential for this DNA cleavage action, and other transition metal ions such as $\mathrm{Fe}^{2+}, \mathrm{Fe}^{3+}, \mathrm{Mn}^{2+}, \mathrm{Co}^{2+}$ and $\mathrm{Zn}^{2+}$ were of no effect. This DNA strand scission was inhibited by catalase (EC 1.11.1.6) and various radical scavengers. This DNA strand scission was caused by free oxygen radicals generated during autoxidation of reduced mitomycin $\mathrm{C}$ in the presence of $\mathrm{Cu}^{2+}$.
\end{abstract}

Mitomycin $\mathrm{C}^{1)}$, an anticarcinogenic antibiotic, contains three functionally reactive moieties in the molecule, such as aziridine, aminoquinone and methylurethane. Its cytotoxicity has been supposed to be due to alkylation and crosslinking, ${ }^{2,3)}$ of DNA. Recently, Lown et al. ${ }^{4)}$ have reported that reduced mitomycin $\mathrm{C}$ induces single strand scission in bacteriophage PM2 double-stranded DNA, and that the DNA strand scission is due to oxygen radicals. However, reduced mitomycin $\mathrm{C}$ does not directly affect double-stranded replicative form I DNA (RF I DNA; supercoiled, covalently closed, circular duplex DNA) of phage $\phi \mathrm{X}^{\left.174^{5}\right)}$ or phage $\phi \mathrm{A}^{8)}$, immunologically related to $\phi \mathrm{X} 174$. On the other hand, we have found that mitomycin $\mathrm{C}$ reduced with sodium hydrosulfite (sodium dithionite, $\mathrm{Na}_{2} \mathrm{~S}_{2} \mathrm{O}_{4}$ ) inactivates in vitro bacteriophage $\phi \mathrm{X} 174$ in the presence of $\mathrm{Cu}^{2+7}$, and that the inactivation of $\phi$ X174 was caused via DNA strand scission of phage single-stranded DNA in the virion by oxygen radicals and mitomycin $\mathrm{C}$ semiquinone radical generated during reduction and autoxidation of mitomycin $\mathrm{C}^{7)}$. A promotive effect of $\mathrm{Cu}^{2+}$ is commonly observed in the phage inactivation reaction by oxygen radical-generating agents ${ }^{8,8,10)}$. We reexamined the effect of mitomycin $\mathrm{C}$ on $\phi \mathrm{X} 174$ doublestranded RF I DNA in the presence of $\mathrm{Cu}^{2+}$.

Mitomycin $\mathrm{C}$ reduced with sodium hydrosulfite caused single strand scission in $\phi$ X174 RF I DNA in the presence of $\mathrm{Cu}^{2+}$. This DNA strand scission was caused by free oxygen radicals generated during autoxidation of reduced mitomycin $\mathrm{C}$ in the presence of $\mathrm{Cu}^{2+}$.

\section{Materials and Methods}

Chemicals and enzymes

Mitomycin C was kindly supplied by Kyowa Hakko Co. Ltd., Tokyo, Japan. Superoxide dismutase (EC 1.15.1.1, bovine blood, 2,900 U/mg protein) and catalase (EC 1.11.1.6, bovine liver, $2,500 \mathrm{U} / \mathrm{mg}$ protein) were purchased from Sigma Chemical Co. Other chemicals were obtained from Nakarai Chemicals Co.

Preparation of $\phi$ X174 RF 1 DNA

Escherichia coli $\mathrm{C}_{\mathrm{N}}$ cells were grown at $37^{\circ} \mathrm{C}$ to $5 \times 10^{8}$ cells $/ \mathrm{ml}$ in 2 liters of TPG-CA medium, 
which is identical to TPG-2A medium ${ }^{11)}$ except that $1 \%$ of Casamino acids is substituted for the amino acids mixture. The cells were infected with $\phi \mathrm{X} 174 \mathrm{am} 3$ at a multiplicity of infection of 5 to 10 . After 9 minutes of incubation, chloramphenicol was added to a final concentration of $30 \mu \mathrm{g} / \mathrm{ml}^{11)}$. The cells were harvested after incubation for further 3 hours, washed with $50 \mathrm{~mm}$ Tris-HCl buffer $(\mathrm{pH} 8.1)$, resuspended in $10 \mathrm{ml}$ of ice-cold $50 \mathrm{~mm}$ Tris- $\mathrm{HCl}$ buffer $(\mathrm{pH} 8.1)$ containing $10 \%$ (w/v) sucrose, and lysed with lysozyme-EDTA and $\mathrm{SDS}^{12)}$. Solid $\mathrm{NaCl}$ was added to the lysate to a concentration of $1 \mathrm{M}$, and the solution was kept on ice for 2 hours. Host DNA and proteins precipitated were removed by centrifugation at $8,000 \times g$ for 10 minutes. The supernatant was incubated with $20 \mu \mathrm{g}$ of RNase $\mathrm{A} / \mathrm{ml}$ (heated to $90^{\circ} \mathrm{C}$ for 10 minutes to inactivate DNase contaminated) at $37^{\circ} \mathrm{C}$ for 30 minutes. Ethidium bromide and $\mathrm{CsCl}$ were then added to give a concentration of 300 to $350 \mu \mathrm{g} / \mathrm{ml}$ and $1.58 \mathrm{~g} /$ $\mathrm{cm}^{3}$, respectively. After centrifugation in a RP65TA rotor of a Hitachi 55P ultracentrifuge at $86,000 \times g$ for 40 hours, the DNA bands were visualized with long-wavelength ultraviolet light $(365 \mathrm{~nm})$. The lower band which contains exclusively $\phi$ X174 RF 1 DNA was collected by aspiration. After this centrifugation step was repeated, ethidium bromide was removed from the DNA by five extractions with isopropyl alcohol saturated with $\mathrm{CsCl}$. $\phi \mathrm{X} 174 \mathrm{RF}$ I DNA suspension was dialyzed against $50 \mathrm{~mm}$ Tris- $\mathrm{HCl}$ buffer ( $\mathrm{pH} 8.1)$.

Reaction of mitomycin C with $\phi$ X174 RF I DNA

The reaction mixture $(20 \mu \mathrm{l})$ contains $0.93 \mu \mathrm{g}(47 \mu \mathrm{g} / \mathrm{ml}) \phi X 174 \mathrm{RF}$ I DNA, $1 \mathrm{~mm}$ mitomycin C, $0.1 \mathrm{~mm}$ sodium hydrosulfite (sodium dithionite, $\mathrm{Na}_{2} \mathrm{~S}_{2} \mathrm{O}_{4}$ ) and $0.01 \mathrm{~mm} \mathrm{CuCl}_{2}$ in $50 \mathrm{~mm}$ Tris- $\mathrm{HCl}$ buffer ( $\mathrm{pH} 8.1$ ), unless otherwise noted. Reaction was carried out for 3 hours at $37^{\circ} \mathrm{C}$, and stopped by addition of $5 \mu \mathrm{l}$ of $0.1 \mathrm{~m}$ EDTA solution containing $50 \%(\mathrm{~W} / \mathrm{V})$ sucrose and $0.1 \%$ bromophenol blue. The sample, a final volume of $25 \mu 1$, was directly analysed by agarose gel electrophoresis.

Agarose gel electrophoresis

Electrophoretic analysis was performed as described by JoHnson and Grossman ${ }^{13)}$. Agarose slab gels $(1.4 \%)$ were run at $3.3 \mathrm{~V} / \mathrm{cm}$ for 4 hours in $40 \mathrm{~mm}$ Tris-acetate buffer $(\mathrm{pH} 8.1)$ containing $5 \mathrm{~mm}$ sodium acetate and $1 \mathrm{~mm}$ EDTA. The gels were run in the presence of $1 \mu \mathrm{g} / \mathrm{ml}$ ethidium bromide, and the stained bands were visualized using an ultraviolet lamp (Chromato-Vue, Transilluminator model C-62) and photographed.

\section{Results}

\section{Interaction of Mitomycin C with $\phi$ X174 RF I DNA}

$\phi X 174$ RF I DNA was not affected by mitomycin $\mathrm{C}$ or mitomycin $\mathrm{C}$ reduced with sodium hydrosulfite (Fig. $1 \mathrm{~B}, \mathrm{C}$ ). As shown in Fig. $1 \mathrm{~F} \sim \mathrm{K}$, in the presence of $0.01 \mathrm{~mm} \mathrm{Cu}{ }^{2+}$, mitomycin $\mathrm{C}$ reduced with sodium hydrosulfite caused DNA strand scission in RF I DNA, and the RF I DNA was converted to RF II DNA (nicked, open circular duplex DNA). The conversion of RF I DNA to RF II DNA was proportional to the concentration of mitomycin C. When the produced RF II DNA was heat-denatured and analyzed using agarose electrophoresis, smaller DNA fragments, other than circular and length of linear single-stranded DNA, were observed (unpublished data). Even when RF I DNA was treated with $5 \mathrm{~mm}$ mitomycin $\mathrm{C}$ in the presence of sodium hydrosulfite and $\mathrm{Cu}^{2+}$ (Fig. $1 \mathrm{~K}$ ), RF III DNA (linear duplex DNA), which is generated by double strand scission in RF I DNA, was not observed. Nonreduced mitomycin C (Fig. 1 D) or sodium hydrosulfite (Fig. 1 E) did not convert RF I DNA to RF II DNA even in the presence of $\mathrm{Cu}^{2+}$. Another reducing agent, sodium borohydride did not serve as a substitute for sodium hydrosulfite, and other transition metal ions such as $\mathrm{Fe}^{2+}, \mathrm{Fe}^{3+}, \mathrm{Mn}^{2+}, \mathrm{Co}^{2+}$ and $\mathrm{Zn}^{2+}$ were of no effect (data not shown).

These results indicate that mitomycin $\mathrm{C}$ reduced with sodium hydrosulfite causes one or more single strand scissions, but not double strand scission, in $\phi$ X174 RF I DNA, and that $\mathrm{Cu}^{2+}$ is essential for this DNA cleavage action. 
Fig. 1. Induction of single strand scission in $\phi$ X174 RF I DNA by mitomycin C in the presence of sodium hydrosulfite and $\mathrm{Cu}^{2+}$.
A : Drug-free control
B : $1 \mathrm{~mm}$ mitomycin C
C : $1 \mathrm{~mm}$ mitomycin C, $0.1 \mathrm{mM} \mathrm{Na}_{2} \mathrm{~S}_{2} \mathrm{O}_{4}$
D : $1 \mathrm{~mm}$ mitomycin C, $0.01 \mathrm{~mm} \mathrm{CuCl}_{2}$
E : $0.1 \mathrm{~mm} \mathrm{Na}_{2} \mathrm{~S}_{2} \mathrm{O}_{4}, 0.01 \mathrm{~mm} \mathrm{CuCl}_{2}$
$\mathrm{F}: \mathrm{E}+0.01 \mathrm{~mm}$ mitomycin C
$\mathrm{G}: \mathrm{E}+0.05 \mathrm{~mm}$ mitomycin $\mathrm{C}$
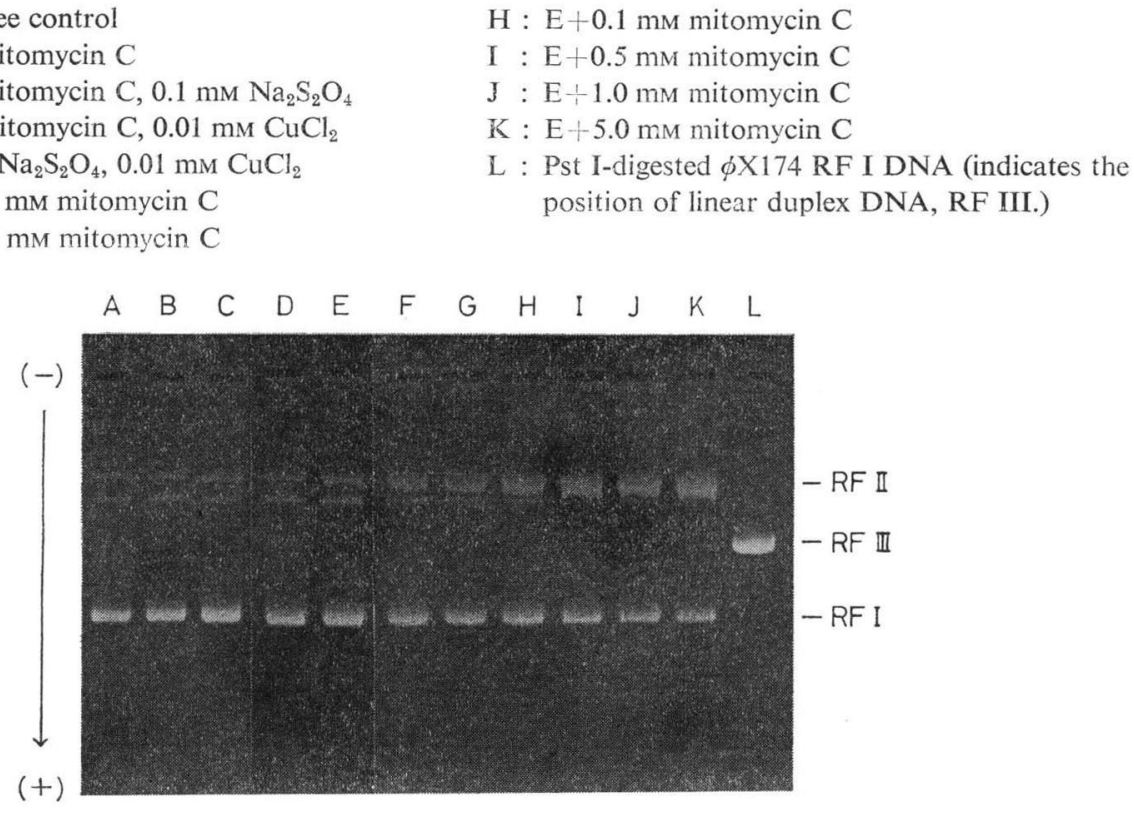

Effect of Enzymes and Radical Scavengers on the RF I DNA Strand Scission by

Mitomycin $\mathrm{C}$ in the Presence of Sodium Hydrosulfite and $\mathrm{Cu}^{2+}$

It is suggested that free oxygen radicals and mitomycin $\mathrm{C}$ semiquinone radical generated during reduction and autoxidation of mitomycin $\mathrm{C}$ are involved in the $\phi \mathrm{X} 174$ single-stranded DNA strand scission and subsequent phage inactivation ${ }^{7)}$. Therefore, enzymes and several radical scavengers were tested for their abilities to inhibit the RF I DNA strand scission by mitomycin $\mathrm{C}$ in the presence of sodium hydrosulfite and $\mathrm{Cu}^{2+}$. As shown in Fig. $2 \mathrm{D}$, catalase $(10 \mu \mathrm{g} / \mathrm{ml})$, which removes hydrogen peroxide, completely inhibited the DNA strand scission. The same concentration of the heat-inactivated enzyme did not inhibit the DNA strand scission (Fig. 2 E). Tiron ${ }^{14)}$, a scavenger for superoxide anion, completely inhibited the DNA strand scission (Fig. 3 C, D), but superoxide dismutase did not inhibit the DNA strand scission (Fig. 2 $F, G)$. This is probably because the enzyme
Fig. 2. Effect of catalase and superoxide dismutase on the induction of single strand scission in $\phi \times 174$ RF I DNA.

A : Drug-free control

B : Complete $(1.0 \mathrm{~mm}$ mitomycin $\mathrm{C}, \quad 0.1 \mathrm{~mm}$ $\mathrm{Na}_{2} \mathrm{~S}_{2} \mathrm{O}_{4}, 0.01 \mathrm{~mm} \mathrm{CuCl}$ )

C : $+1 \mu \mathrm{g} / \mathrm{ml}$ catalase

$\mathrm{D}:+10 \mu \mathrm{g} / \mathrm{ml}$ catalase

E : $+10 \mu \mathrm{g} / \mathrm{ml}$ catalase inactivated by heating for 10 minutes at $100^{\circ} \mathrm{C}$

F : $+10 \mu \mathrm{g} / \mathrm{ml} \mathrm{SOD}$

$\mathrm{G}:+25 \mu \mathrm{g} / \mathrm{ml}$ SOD

$\mathrm{H}:+25 \mu \mathrm{g} / \mathrm{ml}$ SOD inactivated by heating for 10 minutes at $100^{\circ} \mathrm{C}$

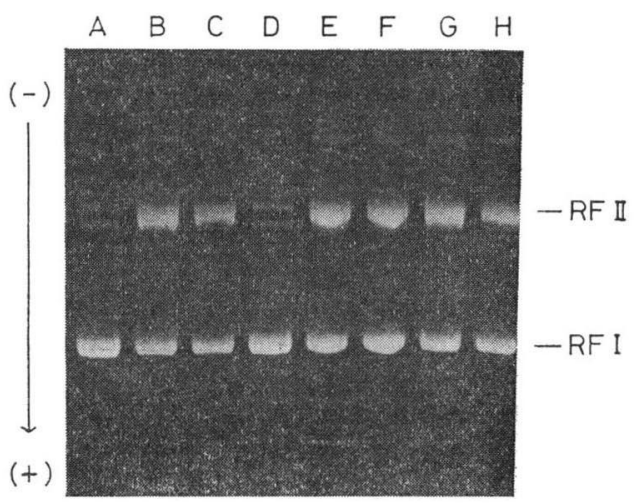


Fig. 3. Effect of radical scavengers on the in duction of single strand scission in $\phi \times 174$ RF I DNA.
A : Drug-free control
$\mathrm{G}:+10 \mathrm{~mm}$ sodium formate
B : Complete (1.0 mm mitomycin C, $0.1 \mathrm{~mm}$
$\mathrm{H}:+100 \mathrm{~mm}$ sodium formate $\mathrm{Na}_{2} \mathrm{~S}_{2} \mathrm{O}_{4}, 0.01 \mathrm{~mm} \mathrm{CuCl}$ )
I : $+0.5 \mathrm{~mm} \mathrm{KI}$
$\mathrm{C}:+0.4 \mathrm{~mm}$ Tiron
$\mathrm{J}:+5.0 \mathrm{~mm} \mathrm{KI}$
D : $+4.0 \mathrm{~mm}$ Tiron
$\mathrm{E}:+10 \mathrm{~mm}$ sodium benzoate
$\mathrm{K}:+1.0$ mм DABCO
$\mathrm{F}:+100 \mathrm{~mm}$ sodium benzoate
$\mathrm{L}:+10 \mathrm{~mm} \mathrm{DABCO}$

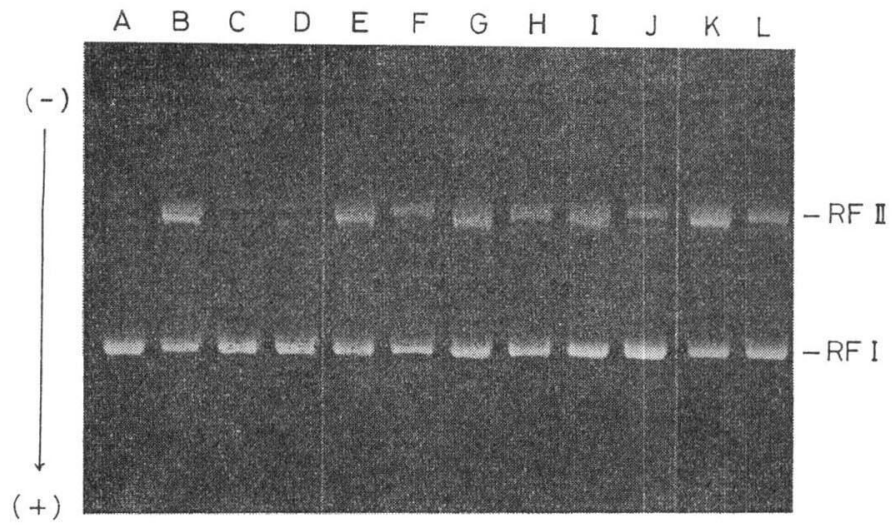

dismutates superoxide anion to oxygen and hydrogen peroxide which produces hydroxyl radical. Sodium benzoate $(100 \mathrm{~mm})$, sodium formate $(100 \mathrm{~mm})$ and potassium iodide $(5 \mathrm{~mm})$, scavengers for hydroxyl radical ${ }^{15}$, inhibited the DNA strand scission (Fig. 3 F, H, J). The DNA strand scission was inhibited also by 1,4-diazabicyclo[2, 2, 2]octane (DABCO) which scavenges singlet oxygen ${ }^{16)}$ (Fig. 3 L).

These results suggest that all of the above mentioned oxygen radicals participate in the RF I DNA strand scission.

\section{Discussion}

The present results reveal that mitomycin $\mathrm{C}$ reduced with sodium hydrosulfite causes single strand scission in $\phi$ X174 double-stranded RF I DNA. $\mathrm{Cu}^{2+}$ is essential for this RF I DNA cleavage in the presence of mitomycin $\mathrm{C}$ reduced with sodium hydrosulfite. Sodium borohydride can not serve as a substitute for sodium hydrosulfite, and other transition metal ions than $\mathrm{Cu}^{2+}$ were of no effect. These characteristics of $\phi$ X174 RF I DNA cleavage very closely resemble those of the $\phi$ X174 phage inactivation and the $\phi \mathrm{X} 174$ single-stranded DNA cleavage produced by action of mitomycin $\mathrm{C}^{7)}$.

The RF I DNA strand scission by mitomycin $\mathrm{C}$ in the presence of sodium hydrosulfite and $\mathrm{Cu}^{2+}$ was inhibited by catalase and various radical scavengers. Oxygen radicals such as superoxide anion, hydrogen peroxide, hydroxyl radical and singlet oxygen are, therefore, suggested to be involved in the $\phi X 174$ RF I DNA strand scission. A possible radical-generating mechanism is as follows;

(1) Mitomycin $\mathrm{C} \stackrel{\mathrm{Na}_{2} \mathrm{~S}_{2} \mathrm{O}_{4}, \mathrm{Cu}^{2+}}{\longrightarrow}$ Mitomycin $\mathrm{C}^{--}$, Mitomycin $\mathrm{CH}_{2}$

(2) Mitomycin $\mathrm{C}^{--}+\mathrm{O}_{2} \longrightarrow$ Mitomycin $\mathrm{C}+\mathrm{O}_{2}{ }^{-}$

(3) Mitomycin $\mathrm{CH}_{2}+\mathrm{O}_{2} \longrightarrow$ Mitomycin $\mathrm{C}^{-}+\mathrm{HO}_{2}+\mathrm{H}^{+}$

(4) Mitomycin $\mathrm{C}^{-}+\mathrm{H}_{2} \mathrm{O}_{2} \longrightarrow$ Mitomycin $\mathrm{C}+\mathrm{OH}^{-}+\mathrm{OH}^{-}$

(5) $\mathrm{HO}_{2} \cdot \rightleftharpoons \mathrm{H}^{+}+\mathrm{O}_{2} \cdot-\mathrm{O}^{-} \quad$ (6) $2 \mathrm{HO}_{2} \cdot \rightleftharpoons \mathrm{H}_{2} \mathrm{O}_{2}+{ }^{1} \mathrm{O}_{2}$

(7) $\mathrm{O}_{2}{ }^{-}++\mathrm{H}_{2} \mathrm{O}_{2} \rightarrow \mathrm{HO}+\mathrm{HO}^{-}+{ }^{1} \mathrm{O}_{2} \quad$ (8) $\mathrm{H}_{2} \mathrm{O}_{2}+\mathrm{H}_{2} \mathrm{O}_{2} \rightarrow 2 \mathrm{H}_{2} \mathrm{O}+{ }^{1} \mathrm{O}_{2}$

(9) $\mathrm{O}_{2} \cdot{ }^{-}+\mathrm{Cu}^{2+} \rightarrow{ }^{1} \mathrm{O}_{2}+\mathrm{Cu}^{+} \quad$ (10) $\mathrm{H}_{2} \mathrm{O}_{2}+\mathrm{Cu}^{+} \rightarrow \mathrm{OH}^{\cdot}+\mathrm{OH}^{-}+\mathrm{Cu}^{2+}$

(11) $\phi$ X174 RF I DNA $+\left\{\begin{array}{l}\mathrm{O}_{2}^{--}, \mathrm{H}_{2} \mathrm{O}_{2}, \mathrm{OH}{ }^{-},{ }^{1} \mathrm{O}_{2} \\ \text { Mitomycin } \mathrm{C}^{--}\end{array}\right\} \rightarrow$ Single strand scission 
Mitomycin C is slowly, non-enzymatically reduced by sodium hydrosulfite to form semiquinone or hydroquinone. On the subsequent rapid autoxidation of the reduced form of quinone, oxygen radicals are produced. Hydroxyl radical is supposed as a responsible species for DNA strand scission by many oxygen radical-generating agents, ${ }^{4,8}$, . The effect of scavengers for hydroxyl radical on the present RF I DNA strand scission suggests that hydroxyl radical is mainly responsible for the $\phi$ X174 RF I DNA strand scission by mitomycin $\mathrm{C}$ in the presence of sodium hydrosulfite and $\mathrm{Cu}^{2+}$. Singlet oxygen may also be involved in the RF I DNA strand scission, because DABCO partly inhibited the conversion of RF I DNA to RF II DNA. Lown et al. ${ }^{4)}$ suggested that strand scission of phage PM2 covalently closed circular (ccc) DNA by reduced mitomycin $\mathrm{C}$ is induced by hydroxyl radical. The $\phi X 174$ RF I DNA cleavage action of mitomycin $C$ is, however, different from the PM2 ccc DNA cleavage action of mitomycin $\mathrm{C}$ in the requirement of $\mathrm{Cu}^{2+}$ and in the availability of sodium borohydride as a reducing agent. Tomasz et al. ${ }^{17)}$ reported that the addition of a large excess of nonreduced mitomycin $\mathrm{C}$ during reduction of mitomycin $\mathrm{C}$ increases the concentration of semiquinone radical, and that mitomycin $\mathrm{C}$ semiquinone radical combines with DNA in a noncovalent manner. Since $\phi$ X174 RF I DNA strand scission was increased when a large excess of mitomycin $\mathrm{C}$ was added against a concentration of sodium hydrosulfite (Fig. $1 \mathrm{I} \sim \mathrm{K}$ ), mitomycin $\mathrm{C}$ semiquinone radical is considered to play an important role in the $\phi$ X174 RF I DNA strand scission. Mitomycin C semiquinone radical has been detected by the electron paramagnetic resonance method and shown to have a lifetime of several seconds ${ }^{18)}$. Oxygen radicals may be generated extremely near DNA at the point where mitomycin $\mathrm{C}$ semiquinone radical is combined, and these oxygen radicals may attack DNA effectively.

\section{Acknowledgement}

This work was supported in part by a scientific grant from the Ministry of Education, Science and Culture, Japan.

\section{References}

1) Hata, T.; Y. Sano, R. Sugawara, A. Matsumae, K. Kanamori, T. Shima \& T. Hoshi: Mitomycin, a new antibiotic from Streptomyces. I. J. Antibiotics, Ser. A 9: 141 146, 1956

2) Small, G. D.; J. K. Setlow, J. Kooistra \& R. Shapanka: Lethal effect of mitomycin C on Haemophilus influenzae. J. Bacteriol. 125: 643 654, 1976

3) IYER, V. N. \& W. SZYBALSKI: A molecular mechanism of mitomycin action: Linking of complementary DNA strands. Proc. Natl. Acad. Sci., U.S.A. 50: 355 362, 1963

4) Lown, J. W.; A. Begleiter, D. Johnson \& A. R. Morgan: Studies related to antitumor antibiotics. V. Reactions of mitomycin $\mathrm{C}$ with DNA examined by ethidium fluorescence assay. Canad. J. Biochem. 54: $110 \sim 119,1976$

5) Lindqvist, B. H. \& R. L. Sinsheimer: The process of infection with bacteriophage $\phi$ X174. XV. Bacteriophage DNA synthesis in abortive infections with a set of conditional lethal mutants. J. Mol. Biol. 30: $69 \sim 80,1967$

6) Taketo, A.: Effect of mitomycin C on the capacity of E. coli to support multipilcation of $\phi$ A. J. Gen. Appl. Microbiol. 21: 185 194, 1975

7) Ueda, K.; J. Morita, K. Yamashita \& T. Komano: Inactivation of bacteriophage $\phi$ X174 by mitomycin $\mathrm{C}$ in the presence of sodium hydrosulfite and cupric ions. Chem.-Biol. Interact. 29: 145 158, 1980

8) Murata, A. \& K. Kitagawa: Mechanism of inactivation of bacteriophage J1 by ascorbic acid. Agric. Biol. Chem. 37: 1145 1151, 1973

9) Wong, K.; A. R. Morgan \& W. Paranchych: Controlled cleavage of phage R17 RNA within the virion by treatment with ascorbate and copper (II). Canad. J. Biochem. 52: 950 958, 1974

10) Kashimura, N.; J. Morita \& T. Komano: Autoxidation and phagocidal action of some reducing sugar phosphates. Carbohydr. Res. 70: C3 C7, 1979

11) Komano T. \& R. L. Sinsheimer: Preparation and purification of $\phi$ X-RF component I. Biochim. Biophys. Acta 155: 295 298, 1968

12) Godson, G. N. \& D. VAPNEK: A simple method of preparing large amounts of $\phi X 174$ RF I supercoiled DNA. Biochim. Biophys. Acta 299: 516 520, 1973 
13) Johnson, P. H. \& L. I. Grossman: Electrophoresis of DNA in agarose gels. Optimizing separations of conformational isomers of double- and single-stranded DNAs. Biochemistry 16: 4217 4225, 1977

14) Greenstock, C. L. \& R. W. Miller: The oxidation of Tiron by superoxide anion. Kinetics of the reaction in aqueous solution and in chloroplasts. Biochim. Biophys. Acta 396: 11 16, 1975

15) Dorfman, L. M. \& G. E. Adams: Reactivity of the hydroxyl radical in aqueous solutions. U.S. Nati. Bur. Standards, U.S. Govt. Printing Office, Washington, 1973

16) OuAnnès, C. \& T. WiLson: Quenching of singlet oxygen by tertiary aliphatic amines. Effect of DABCO. J. Am. Chem. Soc. 90: 6527 6528, 1968

17) Tomasz, M.; C. M. Mercado, J. Olson \& N. Chatterjie: The mode of interaction of mitomycin C with deoxyribonucleic acid and other polynucleotides in vitro. Biochemistry 13: 4878 4887, 1974

18) Nagata, C. \& A. Matsuyama: On the mechanism of action of the carcinostatic antibiotic mitomycin C. Prog. Antimicrob. Anticancer Chemother., Proc. Int. Congr. Chemother., 6th. pp. 423 427, University of Tokyo Press, Tokyo, 1970 